\title{
The Effect of the Universal Child Care Cash Benefit on Female Labour Supply in Spain
}

\author{
ANASTASia HernáNDEZ Alemán a , CARMElo J. LEÓN a , LAURA MÁRQUEZ- \\ RAMOS $^{\text {b }}$ \\ a University Institute of Tourism and Sustainable Economic Development, Las Palmas de Gran \\ Canaria University, Campus Universitario de Tafira, Calle Saulo Torón , 4, 35017 Las Palmas de \\ Gran Canaria, Spain.E-mail: anastasia.hernandez@ulpgc.es; cleon@daea.ulpgc.es \\ b Institute for International Trade, University of Adelaide, Level 6, 10 Pulteney Street, Adelaide SA \\ 5005 Australia.E-mail: laura.marquez-ramos@adelaide.edu.au
}

\begin{abstract}
The aim of this paper is to measure the potential and real effect of universal child care cash benefit schemes on female labour supply. This subsidy, which was considered ground-breaking due to the fact that it was available to all, was introduced through the Spanish Government Act 35/2007 (BOE, 2007) and was in effect until 2010. Known as the "baby bonus", this subsidy of €2,500 per child born aimed to increase the birth rate in Spain. The introduction of this family policy provides a unique setting for a quasi-experiment, using semi-parametric DiD analysis and individual panel data sourced from the EU-SILC dataset. The results provide evidence of the positive effect of a cashfor-care subsidy that reduces the costs of a new child and increases female labour supply.
\end{abstract}

Keywords: Female Labour Supply, Spanish “Baby Bonus”, DiD Method.

\section{Efecto de la prestación monetaria universal para el cuidado de hijos en la oferta de trabajo femenina en España}

\begin{abstract}
RESUMEN
El objetivo de este estudio consiste en analizar el impacto potencial y real de la prestación monetaria universal para el cuidado de hijos en la participación de la mujer en el mercado de trabajo. Dicha medida innovadora por ser "universal" fue introducida con la aprobación de la Ley 35/2007 (BOE, 2007), y estuvo vigente hasta el año 2010. La medida conocida como "“cheque-bebé" consistió en una aportación de $2.500 €$ por nacimiento con el objetivo de estimular la tasa de natalidad. Esta medida proporciona un escenario único para realizar un cuasi-experimento. Para ello se emplea DiD semiparamétrico y regresión con panel de datos individuales, tomando como base la ECV en datos longitudinales para el periodo 2007-2010. Los resultados obtenidos prueban el efecto positivo de la medida en la oferta de trabajo femenino en España al tiempo que reduce los costes del nuevo hijo.

Palabras clave: Participación femenina en el mercado de trabajo, "cheque bebé", método DiD.
\end{abstract}

Clasificación JEL: J13, J18, J22

Artículo recibido en febrero de 2017 y aceptado en junio de 2017

Artículo disponible en versión electrónica en la página www.revista-eea.net, ref. ə-35303

ISSN 1697-5731 (online) - ISSN 1133-3197 (print) 


\section{INTRODUCTION}

Most OECD countries have seen a progressive decline in their birth rates in recent years. The most significant decline occurs in most countries between 1970 and 1995, falling from an average of 2.67 children per woman ${ }^{1}$ to 1.69 , below the replacement level. In a number of countries such as Norway, Sweden, the United Kingdom and France, the fall partially recovers between 1995 and 2010. In others, such as Finland and Denmark, the level remains practically the same throughout the whole period. As the birth rate decreases, there is a continuous and progressive increase in both female employment and the participation of women in the labour market. Historically, this negative relationship is the one most frequently encountered, with the real wages of women, together with the opportunity cost of not working, on the rise, how it is observed in Fig. 1 (1980). In this process of 'recovery', family-policy measures aimed at encouraging the birth rate to rise and enabling parents to achieve a work-life balance have played an important role. Public child care policy is supposed to help families reconcile work and family life and increase parents' participation in the workforce. In recent years, a positive correlation has been found between fertility and female participation in the labour market in some countries (Fig. 1: 2010).

Figure 1

Total Fertility Rate/Female Employment Rate

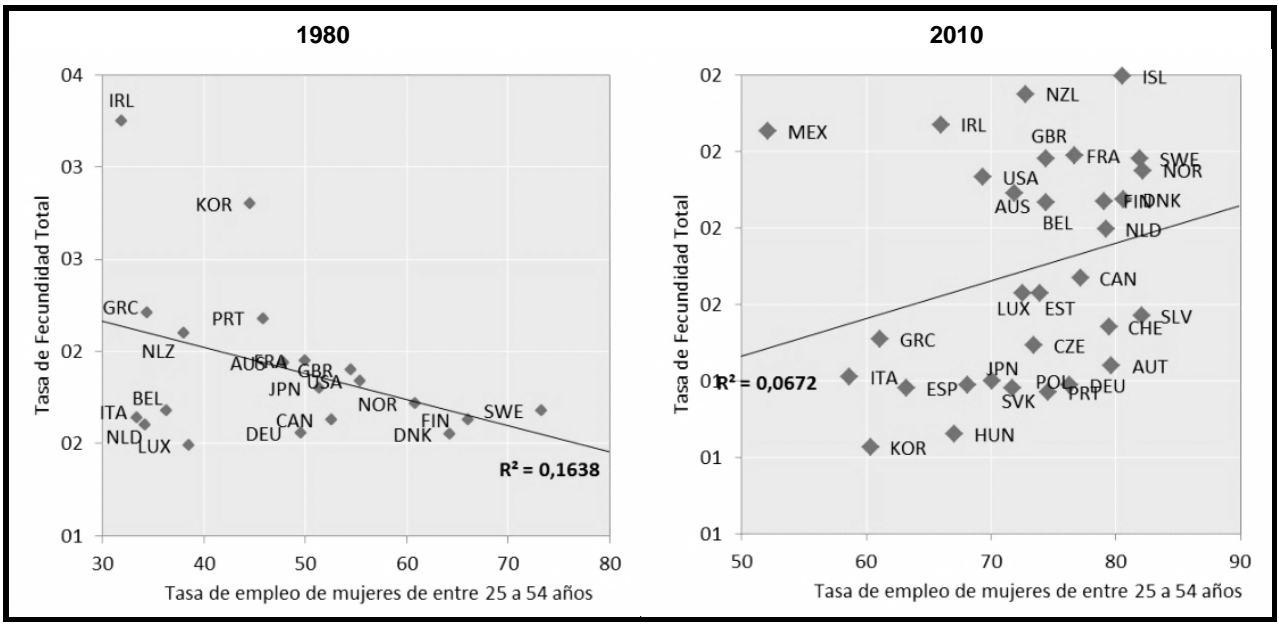

Source: Employment rates - OECD Employment Outlook UN World Statistics Pocketbook, 2010; Fertility rates - National statistical authorities, UN Statistical Division and Eurostat Demographic Statistics, 2010.

${ }^{1}$ Source: OECD. 
In Spanish case, the fertility rate with an average of 1.27 children per woman $^{2}$ and the female labour force participation rate of $50.3 \%$ are lower than the European Union average (1.55 children per woman in EU_28 and 60\% of female labour force participation rate $)^{3}$. Spain has one of the lowest fertility rates in the world (Fig. 2), a situation that is exacerbated by decreasing marriage rates, the older average age of maternity and increasing life expectancy at birth. This reason leads us to believe that not enough effort has been made to reconcile having children and the full inclusion of women in labour markets. In this sense, Aldaz and Eguía (2016), Martínez et al., (2011) and Vega et al., (2016) among others, analyse the process unequal of the incorporation of women to responsibility positions in Spain. In the family unit, women primarily take responsibility for the care of the children (Martínez et al., opus cit.). Results from the Economically Active Population Survey (Spanish National Institute of Statistics) indicate that in 2007 only $0.53 \%$ of employed men applied for paternity leave, whereas $7.48 \%$ of employed women and $10.12 \%$ of employed women of reproductive age (16 to 45 ) took maternity leave (Table A1, appendix). By 2011, the percentage of men had risen to $1.10 \%$ on average, and for women, the percentage had also risen to $8.60 \%$ and $12.34 \%$, respectively. The EU-SILC ${ }^{4}$ 2007-2010 reported that between 2007 and 2008, $26.14 \%$ of women are dedicated to the care of children or other dependents. This percentage increased to 27.47\% between 2009 and 2010; the corresponding values for men were $0.07 \%$ and $0.15 \%$, respectively. The percentage increases to $40 \%$ in women aged 51-65 years, where a disconnection from the workforce has already taken place. The difficulty in maintaining the job or the difficulty in reconciling work and family life after having children can sometimes lead to a definitive separation from the labour market (De la Rica and Iza, 2005).

In response to the gradual aging of the Spanish population, resulting not only from increased life expectancy but also from the significant decline in fertility, in November 2007 the Spanish Government published Act 35/2007 (BOE, 2007). This measure significantly increased the amount of monetary support available to women having children. It was a universal measure that affected both women already active in the workforce and women who were not. The subsidy, in principle, was conceived as an incentive to stimulate the birth rate, but given the background discussed above, and the low level of female labour force participation in Spain, this measure was also expected to have a positive effect on the supply of working women. Moreover, the ratio between family child care benefits and average net salary was not high enough for the income

\footnotetext{
${ }^{2} 1.53$ children per non-Spanish woman and 1.23 children per Spanish woman (2013). Source: INE.

${ }^{3}$ Source: EUROSTAT, 2013.

${ }^{4}$ European Union Statistics on Income and Living Conditions.
} 
effect to compensate for a lower number of hours of work. Our baseline hypothesis is that in countries with low female labour force participation, as is the case of Spain, this type of policy measure fosters the participation of women in the labour market. If so, the universal child care cash benefit in Spain can be considered an appropriate measure to encourage a rise in birth rates, especially in the context of the austerity measures that have plagued Europe in recent years, increasing economic and social inequalities, particularly to the detriment of women.

Figure 2

Total Fertility Rate (\%)

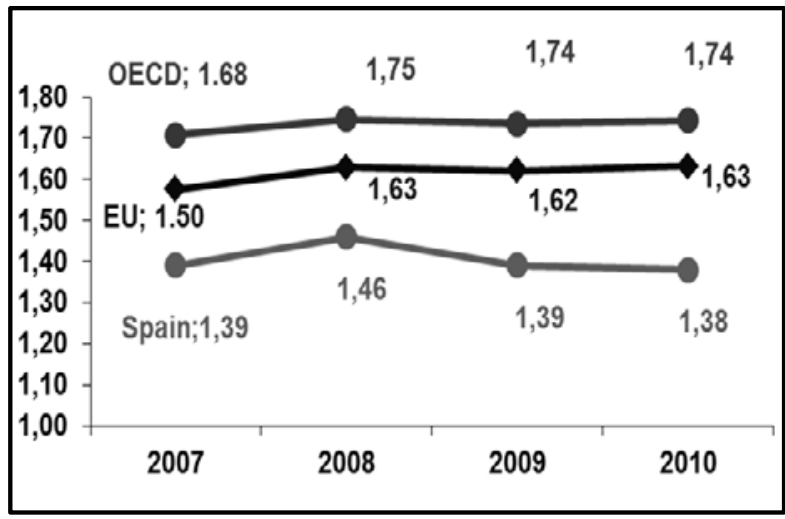

Source: Eurostat and OECD.

The rest of the paper is organized as follows. Section 2 presents a summary of previous research on this topic. The data and variables used in the analysis are discussed in Section 3. Section 4 presents the empirical strategy and the obtained results. Finally, Section 5 presents the conclusions and policy implications.

\section{LITERATURE REVIEW}

There is a considerable amount of literature on child care and female labour supply. Heckman (1974) showed that an increase in child care costs reduces the labour supply of mothers and the number of hours worked. Theoretically, if the cost of having children is reduced, the demand for children increases (Cigno, 1991). However, this increased liquidity could be allocated to providing a higher quality upbringing. In general, the theory predicts that a child care subsidy produces a substitution effect and an income effect. Schøne (2004) states that both effects move in the same direction, leading to a reduction in labour supply. If child care support is available, family budgets increase, and if leisure is considered a normal good, there is a preference for more leisure 
activities and labour supply falls. However, Bauernschuster and Schlotter (2015) support the hypothesis that marginal decreases in the cost of child care do not affect the labour supply of mothers if employment rates and rates of the care of children, are high. Most research to date shows that child care subsidies lead to a rise in the participation of women in the labour market (Bos et al., 1999; Granger and Cryton, 1999; Blau and Tekin, 2007). Nevertheless, when both the participation of women in the labour market and the working hours are very high, the subsidy might not generate increased participation in the labour market but rather the opposite, so participation in the labour force might fall as more hours are devoted to child care (Naz, 2004). The subsidy produces an income effect that compensates for lost wages by reducing work hours offered.

Literature on the impact of measures to reduce the cost of child care includes a number of studies that prove the positive impact of cash benefits on the fertility rate (Barmby and Cigno, 1990; González, 2013). However, these results vary from one country to the next in relation with the labour supply of women (Gauthier and Hatzius, 1997; Laroque and Salanie, 2003; Del Boca, 2002). We also found other studies of countries where the monetary cost of child care had no impact on the labour supply of women (Del Boca and Vuri, 2007; Lundin, Mork and Ockert, 2008). The impact of cash benefits on the participation of women in the labour market differs according to their individual starting conditions, in addition to personal characteristics such as level of education, salary, age, marital status, number of children, etc. (Naz, 2004; Blau and Tekin, 2007; Viitanen, 2005; Bettendorf, Jongen and Muller, 2012). Overall, there is an ambiguous effect of public policies on female labour force participation (Gruber, 1994; Rønsen, 2001, 2009; Schøne, 2004; Bauernschuster and Schlotter, 2013; Guest and Parr, 2013). Rønsen (2001) shows that with the introduction of cash benefits, mothers move from full-time work to part-time work. Naz (opus cit.,) analyses the impact of a $€ 400$ / month benefit payment to families with children in Norway between the ages of one and three, who do not utilize state-subsidized day care centers. The results show that the reform reduced women's labour force participation. However, the effects depend on women's schooling; in particular, the labour force participation of highlyeducated mothers fell by more than that of mothers with a lower level of education. Havnes and Mogstad (2011) analyse a staged expansion of subsidized child care in Norway. Difference-in-differences estimates reveal that there is little, if any, causal effect of subsidized child care on maternal employment. However, Lefebvre and Merrigan (2008) analyse the new childcare policy ${ }^{5}$ implemented in Québec (Canada) in 1997, finding that the policy

\footnotetext{
${ }^{5}$ Licensed child-care service providers began offering day-care spaces at the reduced fee of $\$ 5.00$ per day per child for children aged 4. By 2000, the policy applied to all children not in kindergarten.
} 
had a large and statistically significant impact on the labour supply of mothers with preschool children.

In Spain, there have been numerous studies analyzing the impact of having children on women's participation in the labour market (De la Rica and Ferrero, 2003; Gutiérrez-Doménech, 2008). More specifically, in the context of the analysis of this paper, Sánchez-Mangas and Sánchez-Marcos (2008) analyse the effect of a monthly cash benefit payment of $€ 100$ per child under three years of age for working mothers that was introduced in Spain in 2003. Their results indicate a small but significant positive effect of the policy with respect to the labour market participation rate for mothers of children under three. In the present study, however, we focus on a universal cash benefit payment that affects women regardless of whether they participate in the labour market or not. Sánchez-Mangas et al., (opus cit.,), and more recently, González (2013) relied on the Labour Force Survey (LFS). Since we use the DiD method in this analysis, we chose not to use the LFS in order to avoid possible bias, as the sample of individuals differs in each quarter (Meyer, 1995; Bertrand, Duflo and Mullainathan, 2004; Vicens Otero, 2008). Moreover, as we can see in the following section, multiple treatment and comparison groups allow us to perform further checks of hypotheses and may allow hypotheses to be refined and alternative explanations to be ruled out (Abadie, 2003; 2005; Meyer, 1995:151). Nollenberger and Rodríguez-Planas (2011) analyse the effects of a large-scale provision of publicly subsidized child care for all three-year olds in Spain in the early 1990s. Their estimates show that the policy led to a sizable increase in employment (8\%) and hours worked (9\%) of mothers with ageeligible (three-year-old) children. These effects persisted over time, however, the effects quickly faded away among mothers without a high-school qualification.

\section{DATA AND VARIABLES}

The European Union Statistics on Income and Living Conditions (EU-SILC 2007-2010) provides the data used for our empirical analysis. It is a nationwide survey on household and personal characteristics as well as labour force participation. This survey includes useful micro data that provide information on variables that affect the decision of whether to participate in the labour market, such as education, income and marital status. It was conceived as a rotating panel survey ${ }^{6}$. So despite not being a pure panel survey, it allows us to

\footnotetext{
${ }^{6}$ For each cycle (year), a quarter of the sample (25\%) is renewed. Every year there is an overlap of three of the four parts (75\%) of the sample from the previous year. For each subsample in this survey, selection follows a two-stage design with stratification of the units of the first stage. The first stage of the survey includes census tracts while the second stage includes mainly family households.
} 
obtain the difference-in-differences (DiD) estimator using one wave of the EUSILC from 2007 to 2010, avoiding the sample attrition from a pure panel. The survey includes longitudinal information, i.e. it refers to the same people at different moments of time. In this case, it tracks a four-year period. One year prior to policy implementation (2007) and the three following years (20082010). The survey consists of four files: basic household data, basic individual data, detailed household data and detailed data from adults. The EU-SILC 20072010 survey contains information on 88,211 households, 72,464 adults of whom 34,472 are men and 37,992 are women.

The analysis is performed on two different criteria of selecting individuals from the same survey. Regarding the first criterion, women are chosen for the treatment group and the control group, taking into account the fertile age and working age of women, respectively ${ }^{7}$. The analysis consists of testing the potential effect of the policy on the working hours of women of fertile age who work. In this case, the treatment group, namely the group potentially affected by the measure, comprises 20- to 50-year-old women and the control group, 51- to 65 -year-old women. The former are women of fertile age and working age, while the latter are only of working age. With respect to the second criterion, those families who received family support for the care of dependent children are selected. In this case, the real impact of the measure is analysed in terms of hours supplied by working women whose household has received child care support.

We have analysed the sample and no structural changes are observed in the behaviour of both groups (treatment and control) during the period of analysis. That is, they are homogeneous groups in terms of characteristics ${ }^{8}$ (marital status, education, employment status, work situation, work experience, health, net income, hours worked per week, receipt of family child care support). For instance, most of the women in the sample are married (54.25\% of the sample as a whole), followed by single (27.97\%) and widowed (12.58\%), with similar distributions in both the treatment and the control groups.

As for education, and with respect to the first selection criterion, the greatest percentage in the treatment group is for higher education levels. Not so in the control group, where the highest percentage is that of elementary education. This tendency continues throughout the entire sample period. There is no structural change in the sample from one cycle to the next. With respect to the second criterion, the most common level of education in the treatment group (women who have received family child care support) is higher education. With respect to the control group (women who have not received family child care

\footnotetext{
${ }^{7}$ Note that Gruber (1994) also takes women of certain ages as the treated group.

${ }^{8}$ The distribution of the sample according to the cycle of the survey and characteristics between groups could be observed on request.
} 
support), the most common level of education is primary education. There is less difference in education levels between the two groups chosen with the second selection criterion. In the treatment group (20-50 years old), 37.02\% of women have the highest level of education in 2007 and 36.20\% in 2010, while in the control group (51-65 years old), the corresponding values are $15.27 \%$ and $19.32 \%$, respectively. As mentioned, the difference between the percentages for the treatment and control groups is lower in relation to the second criterion. In the treatment group (received family child care support), $29.23 \%$ of women have the highest level of education in 2007 and 37.32\% in 2010, while in the control group (without family child care support), the corresponding values are $21.57 \%$ and $24.18 \%$, respectively.

Women's accumulated years of work is very similar throughout the sample period, amounting to around 17 years. By age group, women in the control group (51-65 years old) have slightly more than twice as many years of experience compared to women in the treatment group (20-50 years old). However, in several cases, the difference in work experience between the treatment group and the control group based on whether they received child care support or not, is less than four years.

Regarding employment status, what is surprising is the large percentage of women working part-time and women engaged in housework and child care compared to men. Both work situations in the case of women stand at around $34 \%$ on average, while in the case of men the percentage is less than $2 \%$. However, when the analysis is performed by group, a higher percentage of women aged 20-50 who work full-time is observed (around 50\%). In this group of women, there was a significant decline from 2008 onwards of women engaged in housework and child care, falling from $16.42 \%$ in 2007 to $11.96 \%$ in 2010. Interestingly, and contrary to the treatment group (women of 20-50 years old) where women working full-time predominate, in the control group (women aged 51-65) it is dedication to housework and child care that predominates. Regarding women's employment status, the most recent and frequent change, showing a substantial increase as of 2008, is the transition from employed to unemployed, rising from $29.34 \%$ in 2007 to $43.27 \%$ in 2009. No major differences exist between the treatment and control group, as the same general trend is observed.

As health affects participation in the labour market, we examine group differences in this respect. In general, for women, higher percentages are concentrated in the first three levels of the survey: very good, good and fair health. Percentages are stable throughout the sample period. By age group, the highest percentages remain concentrated in "good" health. Nevertheless, in the control group (51-65 years old) the percentage of "very good" drops considerably. Additionally, disparities in health between the treatment group 
and the control group determined according to the second selection criteria are lower than those between the treatment group and control group determined by age. From this perspective, therefore, the groups are also more homogeneous when taking into account whether women received family child care support or not than with respect to the groups per age.

In relation to the income, the average annual net income of women stands at $€ 5267.69$, lower than the average corresponding amount for men (€8747.31). By cycle, the highest annual average net income (€5490.52) corresponds, within the group of women, to the last cycle. By group, there is a disparity between the treatment group (20-50 years old) and the control group (51-65 years old) in terms of average annual net income. While the treatment group has an average annual income above the average of the group of women with €7097.57 per year in 2007, the control group was below the average (€4439.10). In the treatment and control group by family child care support, the previous disparity is also observed in the first two cycles of the survey. However, this disparity is lower in the last two cycles.

In relation to the hours worked per week, there is no significant difference between groups determined by age, as shown by the test for equality of means. Differences in groups according to whether they receive family support or not, are somewhat larger than in the previous assumption; nonetheless, the test for equality of means shows that these differences are not significant. As for the hours worked according to marital status, separated and divorced work more hours on average. Married women work the fewest hours per week. The same trend is observed in the treatment and control groups.

Following this study of the individual characteristics, it can be seen that the treatment and the control groups determined according to whether or not the family receives child care support are more homogeneous than those groups based on age. We can thus state that, for the DiD analysis, the second selection criterion (whether families received support for the care of dependent children) represents a better criterion than that of selecting individuals by age.

\section{METHOD AND RESULTS}

\subsection{Approach}

To estimate the effect of the reduction of the cost of fertility on female labour supply, we use the DiD approach, which is well-established in labour economics ${ }^{9}$, of increasing use and with sound new methodological contributions (see, for example, Fricke, 2017). The main empirical strategy is as follows. We compare two groups (treatment and control) and two periods (before and after

\footnotetext{
${ }^{9}$ Card and Krueger (1994); Meyer (1995); Bertrand et al., (2004), among others.
} 
the policy change). The DiD estimator requires the treatment and control groups to be the same before and after the application of the measure. The groups are selected according to the condition of the measure so that there is a group, affected by the measure, women aged 20-50 years old (i.e., the treatment group). And another group that is not affected by the measure, women aged 5165 years old (i.e., the control group). A second alternative is considered to distinguish the treatment and control groups according to whether they receive direct family child care support or not. Thus, a second treatment group is made up of women who received child care benefit payments and a second control group is comprised of those who did not. In the first alternative, where the groups are determined only by age, the potential effect of the measure is analysed, while in the second, the actual effect of the measure is analysed in terms of hours worked per week.

The outcome variable is defined as regular hours devoted to the main job before and after implementation of the family policy in both groups and allows us to obtain a measure of its causal impact. The following analysis is performed (Wooldridge, 2010):

$$
A T T=E\left\{Y_{1 t^{\prime}}-Y_{1 t}|D=1\rangle\right\}-E\left\{Y_{0 t^{\prime}}-Y_{0 t}|D=0\rangle\right\}
$$

According to this expression, $Y_{1 t^{\prime}}$ is hours worked by the treatment group following implementation of the policy. $Y_{1 t}$ is hours worked by the treatment group prior to implementation of the policy. $Y_{0 t^{\prime}}$ is hours worked by the control group following implementation of the policy. $Y_{0 t}$ is hours worked by the control group prior to implementation of the policy. $\mathrm{D}$ is a dummy variable which is equal to 1 for the treatment group $(D=1)$ and 0 for the control group. So, the outcome variable in specification (1) is weekly hours of work of the two groups of women during the same time period before and after implementation of the family policy, thus alleviating any macroeconomic shocks occurring during the period under study. To overcome the biases that may result from unobservable characteristics, the sample should be the same throughout the period. This method of estimating DiD allows us to obtain a measure of the causal effect that the reduction of the cost of fertility has on female labour supply. The average treatment effect in the treatment group which is known as ATT (average effect of treatment on the treated) can also be estimated in a regression model as follows:

$$
Y_{i s t}=\alpha+\lambda\left(T=t^{\prime}\right)+\gamma(D=1)+\delta \mathrm{I}_{\text {ist }}+\varepsilon_{\text {ist }}
$$

Where, $Y_{\text {ist }}$ is the result, in this case the hours worked in period t by each individual $i$ in group $s ; \lambda$ denotes the time effect after treatment $\left(\mathrm{T}=\mathrm{t}^{\prime}\right) ; \gamma$ is 
the systematic difference in outcome for treatment group effect $(\mathrm{D}=1) ; \delta$ the treatment effect; $I_{\text {ist }}=1\left(T=t^{\prime}\right) 1(D=1)$ is a dummy variable to control for the treatment effect following implementation of the family policy. Finally, $E\left[\varepsilon_{i s t / s, t}\right\rfloor=0$. To control for the other observable variables in relation to the most significant socioeconomic aspects $\left(\mathrm{X}_{\mathrm{ist}}\right)$ the model is enriched as follows:

$$
Y_{\text {ist }}=\alpha+\lambda\left(T=t^{\prime}\right)+\gamma(D=1)+\delta \mathrm{I}_{\text {ist }}+X_{\text {ist }}^{\prime} \beta+\varepsilon_{\text {ist }}
$$

\subsection{Results}

The ATT effects from DiD are shown in Tables 1 and 2. The period of analysis is 2007-2010, which covers the year prior to implementation of the family policy (2007) and the three following years (2008-2010), in order to analyse the subsequent effect of the adoption of the policy. The estimation of Equation (1) shows that there was an increase in average working hours in the treatment group as a result of the implementation of the family policy and then, as a decrease in the cost of fertility. The average effect was +0.61 as potential effect (see Table 1) and +1.94 as real effect (see Table 2$)^{10}$. In this case, the change in hours worked by women is exclusively due to the policy as the control group is not affected by the measure and the variation of the number of hours worked in this group should only be due to economic circumstances, macroeconomic shocks or preferences. As no structural change is observed under the period under study ${ }^{11}$, and the same sample is considered before and after the implementation of the policy, the change in the hours worked in the treatment group is due to the effect of the policy.

According to the obtained results, the supply of female working hours increases in the treatment group. The "baby bonus" covers the need to increase the number of hours of work for women. So when the cost of fertility is reduced, the non-labour income might help to pay for child care and facilitates increased participation in the labour market. This result makes sense in a

${ }^{10}$ We have experimented with other groups of age and with an alternative survey. For example, when using as the treatment group women aged 16-45 and as the control group women aged more than 45 years old in the EU-SILC 2007-2010, we obtain a positive potential effect of the "baby bonus" measure (+0.57). Otherwise, when relying on information from the Economically Active Population Survey (EAPS), the result is negative (-0.54). This difference in results obtained in the two surveys is most likely due to the different design of the surveys. While in the EAPS each household, once selected, only remains in the survey during six consecutive trimesters, the EUSILC 2007-2010 is a rotating longitudinal panel.

${ }^{11}$ The same pattern of behavior is observed in both groups (data are displayed on request). The test for equality of means of the hours worked shows that there are not significant differences between treatment and control groups. Groups are determined according to age and according to whether they receive family benefits or not. 
country where the participation of women in the labour market is not very high. In fact, in Spain female labour force participation is not only significantly lower than the European average, but the opportunity costs of not working for women are also relatively high as there is a persistent gap between opportunities provided to men and women in modern-day Spain.

Table 1

DiD estimate. EU-SILC 2007-2010. Potential Effect. Eq. (1).

\begin{tabular}{|c|c|c|}
\hline Variable & $\begin{array}{l}\text { Treatment Group: } \\
\text { Women aged between } \\
20 \text { and } 50\left[Y_{1}\right]\end{array}$ & $\begin{array}{c}\text { Control Group: } \\
\text { Women aged between } \\
51 \text { and } 65\left[Y_{0}\right]\end{array}$ \\
\hline $\begin{array}{l}\text { Hours worked per week in } 2007 \\
{\left[Y_{0,1 ; t}\right\rfloor}\end{array}$ & $\begin{array}{c}36.75 \\
(\text { Std. err. }=0.27 ; n=1,398)\end{array}$ & $\begin{array}{c}37.63 \\
(\text { Std. err. }=0.59 ; n=359)\end{array}$ \\
\hline $\begin{array}{l}\text { Hours worked per week between } \\
2008-2010 \quad\left[Y_{0,1 ; t^{\prime}}\right]\end{array}$ & $\begin{array}{c}36.16 \\
(\text { Std. err. }=0.09 ; n=10,070)\end{array}$ & $\begin{array}{c}36.43 \\
(\text { Std. err.= } 0.19 ; n=3,048)\end{array}$ \\
\hline Difference & -0.59 & -1.2 \\
\hline
\end{tabular}

Source: Own elaboration.

$A T T=E\left\{Y_{1 t^{\prime}}-Y_{1 t}|D=1\rangle\right\}-E\left\{Y_{0 t^{\prime}}-Y_{0 t}|D=0\rangle\right\}=[36.16-36.75]-[36.43-37.63]=-0.59+1.2=+0.61$

Table 2

DiD estimate. EU-SILC 2007-2010. Real Effect. Eq. (1).

\begin{tabular}{|c|c|c|}
\hline Variable & $\begin{array}{c}\text { Treatment Group: } \\
\text { Women with family support }\end{array}\left[Y_{D=1}\right]$ & $\begin{array}{c}\text { Control Group: } \\
\text { Women without family } \\
\text { support }\left[Y_{D=0}\right]\end{array}$ \\
\hline Hours worked per week in 2007 & 32.76 & 37.08 \\
\hline$\left[Y_{D=0,1 ; t}\right]$ & $($ Std. err.= 1.09; $n=86)$ & (Std. err. $=0.25 ; n=1694)$ \\
\hline Hours worked per week between & 33.96 & 36.34 \\
\hline 2008-2010 $\left[Y_{D=0,1 ; t^{\prime}}\right]$ & $($ Std. err. $=0.40 ; n=744)$ & $($ Std. err. $=0.09 ; n=11,761)$ \\
\hline Difference & +1.2 & -0.74 \\
\hline
\end{tabular}

Source: Own elaboration.

$$
A T T=E\left\{Y_{1 t^{\prime}}-Y_{1 t}|D=1\rangle\right\}-E\left\{Y_{0 t^{\prime}}-Y_{0 t}|D=0\rangle\right\}=[33.96-32.76]-[36.34-37.08]=1.2+0.74=+1.94
$$

Table 3 summarises the results of the regression analysis for the potential and the real effect, respectively. In a first step, we estimate Equation (2) by OLS (using clustered standard errors). Our results show that the ATT effect is very similar to that obtained by $\mathrm{DiD}$ (Tables 1 and 2). In a second step, we add three control variables to the initial model, as they could affect the supply of hours of work by women: level of education, marital status and family support. The family support variable measures family child care support in the estimated 
model for the treatment and control groups according to age (Table 3 column ii, potential effect).

Table 3

ATT effect estimated by OLS_vce (cluster)

\begin{tabular}{|c|c|c|c|c|}
\hline \multirow{3}{*}{ Independent variables } & \multicolumn{2}{|c|}{ Potential Effect } & \multicolumn{2}{|c|}{ Real Effect } \\
\hline & \multicolumn{4}{|c|}{ Model } \\
\hline & (i) & (ii) & (i) & (ii) \\
\hline Time effect $\lambda$ & $\begin{array}{l}-1.19 \\
(0.00)\end{array}$ & $\begin{array}{c}-1.23 \\
(0.007)\end{array}$ & $\begin{array}{l}-0.73 \\
(0.00)\end{array}$ & $\begin{array}{c}-0.72 \\
(0.002)\end{array}$ \\
\hline Group effect $\gamma$ & $\begin{array}{l}-0.90 \\
(0.00)\end{array}$ & $\begin{array}{c}-1.28 \\
(0.058)\end{array}$ & $\begin{array}{l}-4.31 \\
(0.00)\end{array}$ & $\begin{array}{l}-3.81 \\
(0.01)\end{array}$ \\
\hline ATT $\delta$ & $\begin{array}{c}\mathbf{0 . 6 6} \\
(0.00)\end{array}$ & $\begin{array}{c}\mathbf{0 . 7 7} \\
(0.014)\end{array}$ & $\begin{array}{c}1.94 \\
(0.00)\end{array}$ & $\begin{array}{c}1.71 \\
(0.001)\end{array}$ \\
\hline _cons & $\begin{array}{l}37.63 \\
(0.00)\end{array}$ & $\begin{array}{c}38.83 \\
(0.166)\end{array}$ & $\begin{array}{l}37.08 \\
(0.00)\end{array}$ & $\begin{array}{l}37.87 \\
(0.03)\end{array}$ \\
\hline Level of education & - & $\begin{array}{c}0.61 \\
(0.08)\end{array}$ & - & $\begin{array}{c}0.58 \\
(0.03)\end{array}$ \\
\hline Marital status & - & $\begin{array}{l}-2.04 \\
(0.28)\end{array}$ & - & $\begin{array}{l}-1.95 \\
(0.04)\end{array}$ \\
\hline Family Support & - & $\begin{array}{c}-0.0005 \\
(0.000)\end{array}$ & - & - \\
\hline $\mathrm{R}^{2}$ & 0.007 & 0.0135 & 0.0041 & 0.0139 \\
\hline Root MSE & 10.2 & 10.1 & 10.2 & 10.1 \\
\hline Number of obs. & \multicolumn{2}{|c|}{14,214} & \multicolumn{2}{|c|}{14,285} \\
\hline
\end{tabular}

Source: EU-SILC 2007-2010. Own elaboration.

The results show that the value of the constant term is similar to the average number of hours worked by the group of women during this period; around 36 hours a week. The estimated coefficients present the expected sign. Firstly, the level of education is a dummy variable that takes the value of 1 for women with a higher level of education and 0 otherwise (see Table 4). The sign of the estimated coefficient for this variable is positive indicating that the higher the level of education, in this case, college education, the higher the supply of hours of work compared to the other levels of education. In fact, the higher the level of education, the better the working conditions in terms of wages and working hours tend to be. Thus, the opportunity cost of one hour of work is higher than in the rest of the levels of education. Similarly, a positive correlation is found between income and level of education. Previously, Lemieux (2006) established a direct relationship between the highest level of wages and high levels of education.

Secondly, related literature that analyses the participation of women in the labour market (Fitzpatrick, 2012) usually divides groups according to marital status, and we therefore include this variable as a control in our regression. The marital status variable takes the value of 1 for married women and 0 otherwise. Married women work fewer hours, which is probably due to there being another family income (non-labour income or income of the spouse) and may also be 
due to the dependents of older married women. Family support is a variable introduced only in the model estimated with treatment and control groups according to age, i.e in the analysis of the potential effect (Table 3 column ii). It is a proxy variable of there being children in the household ${ }^{12}$. The estimated coefficient is negative signed and statistically significant and so the existence of children in the household reduces the working hours of mothers. The average effect of treatment on the treated (ATT) remains positive and its quantitative impact is greater in model $i$ than in model $i$. The real effect is higher than the potential effect in both estimations. The estimated coefficients of time and group variables are negative signed. More specifically, the time effect is negative, as well as the supply of working hours in the treatment group. The negative impact obtained for the time effect could be explained by the economic crisis, which is a dummy variable that takes the value of 1 for the period 2008 to 2010 and 0 for 2007. The sign of the coefficient that captures the effect of the group is also negative. Also regarding the results of estimating Equation (3), efficiency and accuracy of the model increases as more regressors are included, as expected, and in particular, when those variables related to individual characteristics-level of education, marital status and family support-are included. The result of the estimation shows that the time effect and the group effect, as well as the impact of the measure (ATT) are statistically significant; the estimated coefficients keep the same sign and almost the same value in terms of magnitude.

Table 4

Definitions of the variables

\begin{tabular}{|l|l|}
\hline \multicolumn{1}{|c|}{ Variables } & \multicolumn{1}{c|}{ Definitions } \\
\hline Dependent variable & Hours of work supplied per week \\
\hline Treatment group (first criterion) & $20-50$ year-old women \\
\hline Control group (first criterion) & 51 to 65 year-old women \\
\hline Treatment group (second criterion) & Working women whose household has received child care support \\
\hline Control group (second criterion) & $\begin{array}{l}\text { Working women whose household doesn't have received child care } \\
\text { support }\end{array}$ \\
\hline Level of education & $\begin{array}{l}\text { Level of education is a dummy variable that takes the value of } 1 \text { for } \\
\text { women with a higher level of education and 0 otherwise }\end{array}$ \\
\hline Marital status & $\begin{array}{l}\text { The marital status variable takes the value of } 1 \text { for married women and } 0 \\
\text { otherwise. }\end{array}$ \\
\hline Family Support & $\begin{array}{l}\text { Dummy variable that takes the value of } 1 \text { if household has received child } \\
\text { care support and } 0 \text { otherwise. }\end{array}$ \\
\hline ATT & The average effect of the measure. \\
\hline
\end{tabular}

Source: Own elaboration.

${ }^{12}$ If financial support for childcare is received, it is because there are children in the household and this affects the hours worked in the case of women. 


\section{CONCLUSIONS AND POLICY IMPLICATIONS}

The primary aim of the paper is to test the effectiveness of a family policy measure, namely the universal child care cash benefit scheme, on the participation of women in the labour market in Spain. Spain is an interesting case study as it has one of the highest unemployment rates in the European Union (second only to Greece) and many social and economic inequalities persist, which may have been exacerbated by the austerity policies implemented in recent years. Additionally, business owners and Spanish society in general do not seem able to overlook the stigma of working mothers of young children. This paper examines whether the universal child care cash benefit scheme has a positive impact on the supply of working hours of women, under the hypothesis that in countries with low female labour force participation, as is the case of Spain, this sort of measure facilitates the participation of women in the labour market. Our results prove the effectiveness of the "baby bonus" in reconciling family life with working life. We find evidence to support our main hypothesis (i.e. that in countries with low female labour force participation, this type of policy fosters the participation of women in the labour market), that translates into a real impact of the policy of an average increase of about two hours per week in the supply of working hours of mothers who received the $€ 2,500$ family support payment (ATT=1.94). This result is robust when individual characteristics are taken into account. The effect is highly relevant, particularly if we take into account the modest size of the "baby bonus", the short period of time that it was available and the barriers that exist when it comes to accessing public day care. This sort of universal family policy facilitates the participation of mothers in the labour market and most likely helps women overcome the economic obstacles that delay or prevent women having children.

\section{BIBLIOGRAPHY REFERENCES}

ABADIE A. (2003). "Semiparametric instrumental variable estimation of treatment response models". Journal of Econometrics, 113, pp. 231-263.

ABADIE A. (2005). "Semiparametric Difference in Differences Estimators". Review of Economic Studies, 72, pp. 1-19.

ALDAZ ODRIOZOLA L. and B. EGUÍA PEÑA (2016). "Segregación laboral por género en España y en el País Vasco. Un análisis de cohortes". Estudios de Economía Aplicada, 34(1), pp. 133-154.

BARMBY, T., and A. CIGNO (1990). "A sequential probability model of fertility patterns". Journal of Population Economics, 3, n¹, pp. 31-51.

BAUERNSCHUSTER, S., and M. SCHLOTTER (2015). "Public child care and mothers' labor supply-Evidence from two quasi-experiments". Journal of Public Economics, 123, pp. 1-16. 
BERTRAND, M., E. DUFLO and S. MULLAINATHAN (2004). "How much should we trust differences-in-differences estimates?". Quarterly Journal of Economics, 119, pp. 249275.

BETTENDORF, L., E. JONGEN and P. MULLER (2012). "Childcare subsidies and labour supply: evidence from a large Dutch reform". CPB Discussion Paper, $n^{\circ} 217$. CPB Netherlands Bureau for Economic Policy Analysis.

BLAU, D. M., and E. TEKIN (2007). "The Determinants and Consequences of Childcare Subsidies for Singles Mothers". Journal of Population Economics, 20, n 4, pp. 71941.

BOE- Boletín Oficial del Estado (2007). Law 35/2007, 15 November, por la que se establece la deducción por nacimiento o adopción en el Impuesto sobre la Renta de las Personas Físicas y la prestación económica de pago único de la Seguridad Social por nacimiento o adopción. Available at http://www.boe.es/diario_boe/txt.php? id=BOE-A-2007-19745\&lang=en

BOS J. M., A. C. HUSTON, R. C. GRANGER, G. J. DUNCAN, T. W. BROCK, and V. C. MCCLOYD (1999). New Hope for People with Low Incomes: Two-Year Results of a Program to Reduce Porverty and Reform Welfare. New York: Manpower Demonstration Research Corp.

CARD, D., and A. B. KRUEGER (1994). "Minimum Wages and Employment: A Case Study of the Fast-Food industry in New Jersey and Pennsylvania". The American Economic Review, vol. 84, no 4, pp. 772-793.

CIGNO, A. (1991). Economics of the Family. Oxford University Press. Oxford.

DE LA RICA, S., and A. IZA (2005). "Career planning in Spain: do fixed-term contracts delay marriage and parenthood?". Review of the Economics of the Household 3(1), pp. 49-73.

DE LA RICA, S., and M. D. FERRERO (2003). "The effect of fertility on labour force participation: the Spanish evidence". Spanish Economic Review, 5, nº 2, pp.153-172.

DEL BOCA, D. (2002). "The Effect of childcare and part-time on participation and fertility of Italian women". Journal of Population Economics, 15, n 3, pp. 549-73.

DEL BOCA, D., and D. VURI (2007). "The mismatch between employment and child care in Italy: the impact of rationing". Journal of Political Economy $20, n^{\circ} 4$, pp. $805-$ 832.

FITZPATRICK, M. D. (2012). "Revising our Thinking about the Relationship between Maternal Labor Supply and Preschool". The Journal of Human Resources 47, n 3 , pp. 83-612.

FRICKE, H. (2017). "Identification Based on Difference-in-Differences Approaches with Multiple Treatments". Oxford Bulletin of Economics and Statistics, 79, $\mathrm{n}^{\circ} 3$, pp. 426 433.

GAUTHIER, A. H., and J. HATZIUS (1997). "Family benefits and fertility: an econometric analysis". Population Studies, 51, n⿳0 3, pp. 294-306.

GONZÁLEZ, L. (2013). "The effect of a universal child benefit on conceptions, abortions, and early maternal labor supply". American Economic Journal: Economic Policy, 5, $\mathrm{n}^{\mathrm{o}}$ 3, pp. 160-188.

GRANGER, R. C., and R. CRYTON (1999). "Teenage Parent Programs: A Synthesis of the Long Term Effects of the New Chance Demonstration, Ohio's Learning, Earning and Parenting Program, and the Teenage Parent Demonstration". Evaluation Review, 23, $n^{\circ} 2$, pp. 107-45. 
GRUBER, J. (1994). "The incidence of mandated maternity benefits". American Economic Review, 84, pp. 622-641.

GUEST, R., and N. PARR (2013). "Family policy and couples' labour supply: an empirical assessment". Journal of Population Economics, 26, pp. 1631-1660.

GUTIÉRREZ-DOMÉNECH, M. (2008). "The impact of the labor market on the timing of marriage and births in Spain". Journal of Population Economics, 21, pp. 83-110.

HAVNES, T., and M. MOGSTAD (2011). "Money for nothing? Universal Child Care and Maternal Employment". Journal of Public Economics 95, no 11-12, pp. 1455-1465.

HECKMAN, J. J. (1974). "Shadow prices, market wages and labor supply". Econometrica, 42, pp. 679-694.

LAROQUE, G., and B. SALANIE (2003). Fertility and financial incentives in France. Mimeo (eds.)

LEFEBVRE, P., and P. MERRIGAN (2008). "Child-care policy and the labor supply of mothers with young children: a natural experiment from Canada". Journal of Labor Economics, 26, n 3, pp. 519-548.

LEMIEUX, T. (2006). "Post-Secondary Education and Increasing Wage Inequality". NBER Working Paper, $\mathrm{n}^{\circ}$ 12077. March.

LUNDIN, D., E. MORK, and B. OCKERT (2008). "How far can reduced childcare prices push female labour supply?". Labour Economics, 15, pp. 647-659.

MARTÍNEZ MARTÍN, M. I., N. GUILLÓ RODRÍGUEZ, R. SANTERO SÁNCHEZ and R. B. CASTRO NÚÑNEZ (2011). Trayectorias Laborales de las mujeres que ocupan puestos de alta dirección, Madrid: Ministerio de Sanidad, Política Social e Igualdad Centro de Publicaciones.

MEYER B. D. (1995). "Natural and Quasi-Experiments in Economics". Journal of Business \& Economic Statistics, 13(2), pp. 151-62.

NAZ, G. (2004). "The impact of cash-benefit reform on parents' labour force participation". Journal of Population Economics, 17, pp. 369-383.

NOLLENBERGER, N., and N. RODRíGUEZ-PLANAS (2011). "Child care, maternal employment and persistence: a natural experiment from Spain". IZA Discussion Paper $\mathrm{n}^{\circ} 5888$, July

RØNSEN, M. (2001). "Market work, child care and the division of household labor". Statistics Norway Report 2001/3, Oslo.

RØNSEN,, M. (2009). "Long-term effects of cash for childcare on mothers' labour supply". Labour 23, n 3, pp. 507-533.

SÁNCHEZ-MANGAS, R., and V. SÁNCHEZ-MARCOS (2008). "Balancing family and work: the effect of cash benefits for working Mothers". Labour Economics, 15, pp. 1127-1142.

SCHØNE, P. (2004). "Labour supply effects of a cash-for-care subsidy". Journal of Population Economics, 17, pp. 703-727.

VEGA CATENA P. J., R. SANTERO, B. CASTRO and N. GÓMEZ (2016). "Participación femenina en puestos directivos y desigualdad salarial. Un análisis en el mercado laboral español". Estudios de Economía Aplicada, 34(1), pp. 155-178.

VICENS OTERO J. (2008): "Problemas econométricos de los modelos de diferencias en diferencias". Estudios de Economía Aplicada, 26(1), pp. 363-384.

VIITANEN, T. K. (2005). "Cost of Childcare and female employment in the U.K.". Labour (special issue), 19(S1), pp.149-170.

WOOLDRIDGE J. M. (2010). Econometric Analysis of Cross Section and Panel Data, London: The MIT Press. 


\section{APPENDIX}

Table 1A

Reasons for not working, with a job. Maternity/Paternity Leave (=1). Extended leave of absence to raise children (=2). LFS 2007-2012. \%

\begin{tabular}{|c|c|c|c|c|c|c|c|c|c|}
\hline \multirow{2}{*}{ Period } & \multicolumn{3}{|c|}{ Males } & \multicolumn{3}{|c|}{ Females } & \multicolumn{3}{|c|}{ Females between 16 and 45 years } \\
\hline & 1 & & 2 & & & 2 & 1 & & 2 \\
\hline 2007_1t & 0.24 & \multirow{4}{*}{0.53} & 0.19 & 8.48 & \multirow{4}{*}{7.48} & 5.05 & 11.55 & \multirow{4}{*}{10.12} & 6.82 \\
\hline 2007_2t & 0.74 & & 0.05 & 10.57 & & 4.57 & 14.20 & & 6.14 \\
\hline 2007_3t & 0.34 & & 0.05 & 3.79 & & 1.81 & 5.06 & & 2.39 \\
\hline $2007 \_4 \mathrm{t}$ & 0.80 & & 0.21 & 7.09 & & 4.83 & 9.70 & & 6.61 \\
\hline 2008_1t & 1.30 & \multirow{4}{*}{0.93} & 0.11 & 7.94 & \multirow{4}{*}{7.73} & 4.53 & 10.70 & \multirow{4}{*}{10.49} & 6.11 \\
\hline 2008_2t & 1.13 & & 0.16 & 10.53 & & 7.28 & 14.24 & & 9.77 \\
\hline 2008_3t & 0.44 & & 0.03 & 3.96 & & 2.56 & 5.38 & & 3.46 \\
\hline 2008_4t & 0.87 & & 0.08 & 8.50 & & 5.33 & 11.66 & & 7.21 \\
\hline 2009_1t & 0.96 & \multirow{4}{*}{0.90} & 0.12 & 8.82 & \multirow{4}{*}{7.76} & 6.07 & 12.03 & \multirow{4}{*}{10.62} & 8.17 \\
\hline 2009_2t & 1.26 & & 0.30 & 9.38 & & 6.65 & 12.78 & & 8.82 \\
\hline 2009_3t & 0.45 & & - & 3.64 & & 2.49 & 5.04 & & 3.39 \\
\hline 2009_4t & 0.95 & & 0.08 & 9.23 & & 5.79 & 12.66 & & 7.83 \\
\hline 2010_1t & 0.81 & \multirow{4}{*}{0.95} & 0.17 & 9.94 & \multirow{4}{*}{8.84} & 5.93 & 13.97 & \multirow{4}{*}{12.40} & 8.20 \\
\hline 2010_2t & 1.30 & & 0.11 & 11.49 & & 6.95 & 16.05 & & 9.51 \\
\hline 2010_3t & 0.44 & & 0.11 & 3.96 & & 2.58 & 5.51 & & 3.58 \\
\hline 2010_4t & 1.28 & & 0.24 & 9.98 & & 4.91 & 14.10 & & 6.94 \\
\hline 2011_1t & 1.38 & \multirow{4}{*}{1.10} & 0.06 & 10.22 & \multirow{4}{*}{8.60} & 5.92 & 14.73 & \multirow{4}{*}{12.34} & 8.58 \\
\hline 2011_2t & 1.46 & & 0.28 & 9.23 & & 5.43 & 13.34 & & 7.88 \\
\hline 2011_3t & 0.48 & & 0.10 & 4.23 & & 2.02 & 6.06 & & 2.84 \\
\hline 2011_4t & 1.11 & & 0.04 & 10.74 & & 3.77 & 15.25 & & 5.32 \\
\hline 2012_1t & 1.61 & \multirow{4}{*}{0.99} & 0.16 & 13.23 & \multirow{4}{*}{9.71} & 4.38 & 19.32 & \multirow{4}{*}{14.28} & 6.35 \\
\hline 2012_2t & 0.92 & & 0.06 & 10.41 & & 4.20 & 15.49 & & 6.16 \\
\hline 2012_3t & 0.42 & & 0.02 & 3.80 & & 1.66 & 5.65 & & 2.49 \\
\hline 2012_4t & 1.01 & & 0.14 & 11.42 & & 3.40 & 16.67 & & 4.98 \\
\hline
\end{tabular}

Source: Economically Active Population Survey (Spanish National Institute of Statistics). 